\title{
Evaluation stasis continues in PR and corporate communication: Asia Pacific insights into causes
}

\author{
Jim Macnamara \\ University of Technology Sydney \\ Ansgar Zerfass \\ University of Leipzig
}

\begin{abstract}
The first comprehensive study of public relations (PR) and corporate communication practices across Asia-Pacific countries has found that, despite being an area of rapid growth, evaluation remains limited, is often not based on reliable research methods, and is focussed on outputs rather than the outcomes of communication. This reflects a worldwide stasis in evaluation of PR that has been identified as problematic by a number of authors. The Asia-Pacific Communication Monitor, a survey-based study conducted by a collaboration of 16 universities across 23 Asia-Pacific countries in 2015, also explored practitioners' skills, and found a significant lag that could account for this stasis. This article reports key findings of this study that contribute insights to address the lack of measurement and evaluation in the growing field of PR that remains a major concern in the academy and industry.
\end{abstract}

Keywords: PR, measurement, evaluation, outputs, outcomes, impact, skills

\section{0 years of debate on the effects and value of PR}

Interest in measurement and evaluation of public relations dates back to the pioneering US practitioner Edward Bernays, who saw PR as an applied social science that should be planned using opinion research and "precisely evaluated" (Watson, 2012, p. 391), and scholarly attention has been focussed on measurement and evaluation of PR for 50 years or more (Likely \& Watson, 2013; Volk, 2016). Literature on the importance of research for PR measurement and evaluation (M\&E for short) began to appear in the late 1950s when the second edition of Effective Public Relations was published. After advocating public opinion research in the first edition (Cutlip \& Center, 1952), their second edition (Cutlip \& Center, 1958) added evaluation as the fourth step in the "PR process" after "fact-finding, planning and communicating" (Hallahan, 1993, p. 198).

Likely and Watson (2013), Watson (2012) and Watson and Noble (2014) identify a concerted focus on M\&E of PR and corporate communication from the 1970s. Likely and Watson (2013) say a conference organised and chaired by now retired Emeritus Professor Jim Grunig at the University of Maryland in 1977 was a "prime catalyst" for academic attention to M\&E, as well as a special issue of Public Relations Review on 'Measuring the effectiveness of public relations' published in the same year. Other landmark publications in the 1970s and the early 1980s included the work of Broom and Dozier (1983) and Dozier $(1984,1985)$; along with Jim Grunig's continued advocacy (Grunig, 1979, 1983); the sixth edition of Effective Public Relations in which Cutlip, Center and Broom (1985) presented their Planning, Implementation, Impact (PII) model; and articles by some leading practitioners such as Walter Lindenmann of Ketchum Public Relations (1979, 1980). 
In a pioneering book on PR research published in the late 1980s, Pavlik (1987) compared measurement and evaluation to the Holy Grail - a view echoed by L'Etang in the twenty-first century when she noted critically that "evaluation has become and remains something of a 'holy grail' for public relations” (2008, p. 26). Pavlik's rallying call was followed soon after by another landmark book on research for measurement and evaluation of PR and corporate communication, Using Research in Public Relations: Applications to Program Management by Broom and Dozier (1990). These two specialist books on research for PR, along with general PR texts such as Grunig and Hunt's (1984) Managing Public Relations, meant that clear guidelines on methodology and methods for M\&E were available to PR academics and practitioners by 1990 .

Following the PII model, a number of other models of PR research for measurement and evaluation were published in a period of escalating development of M\&E literature during the 1990s, including the PR Effectiveness Yardstick (Lindenmann, 1993); the Macro Model of Evaluation (Macnamara, 1999), which evolved into the Pyramid Model of PR Research (Macnamara, 2012); the Short Term Model and Continuing Model of Evaluation (Watson, 1997; Watson \& Noble, 2014, p. 65); and the Unified Evaluation Model (Noble \& Watson, 1999; Watson \& Noble, 2007, 2014). Drawing on theory of change and logic models that are widely used in program evaluation in other fields (Clark \& Taplin, 2012; Julian, 1997; Kellogg Foundation, 2004; Knowlton \& Phillips, 2013), these models identified key stages of measurement and evaluation, such as inputs, outputs, and outcomes, or impact, and emphasised the final stage. Some identified specific research methods for calculating and demonstrating the returns from and value of PR and corporate communication.

The 2000s saw an ever-growing body of epistemological and methodological contributions in relation to M\&E. In the influential Excellence study of PR, L. Grunig, J. Grunig and Dozier (2002) used a compensating variation approach to benefit cost ratio (BCR), also referred to as cost benefit analysis (CBA), to deal with the challenge of evaluating intangibles, based on earlier work by Ehling (1992). Compensating variation is based on a simple idea: ask stakeholders how much they would be willing to pay for a non-monetary benefit. In the Excellence study, the researchers found that most CEOs agreed that PR contributed value to their organization, but determining a specific financial or other quantification of value remained elusive.

A number of attempts have been made to apply other measurement methods to evaluate PR and corporate communication such as cost effectiveness analysis (CEA) proposed by Likely (2012; see also Likely and Watson, 2013); market mix modelling (Weiner, 2006); and communication controlling or communication performance management (Zerfass, 2010). PR also has attempted to use various calculations of return on investment (ROI), but a review by Watson and Zerfass (2011, 2012) has dismissed such attempts because of use of ROI for PR evaluation in "loose" and "fuzzy" ways.

Industry bodies also have produced position statements, manuals, and guides on M\&E. Most recently these have included The Barcelona Principles, a set of seven guiding principles endorsed by professional organisations worldwide that were first developed in 2010 and revised in 2015 (AMEC, 2015a), as well as guides and standards for practitioners produced by professional organisations such as the Association for Measurement and Evaluation of Communication (AMEC, 2015b), the Institute for Public Relations in the US (IPR, 2015), and the Public Relations Institute of Australia (PRIA, 2014).

An extensive body of literature on how to conduct M\&E of PR and corporate communication has been established and is only briefly summarised here as it has been reviewed in detail in a 
number of analyses including Likely and Watson (2013), Macnamara (2015), Stacks and Michaelson (2014), and Watson and Noble (2014).

Table 1. The Barcelona Principles of PR and communication measurement as drafted in 2010 and as revised in 2015 (AMEC, 2015a).

\begin{tabular}{ll}
\hline Barcelona Principles 2010 & Barcelona Principles 2.0 \\
\hline Importance of goal setting and measurement & $\begin{array}{l}\text { Goal setting and measurement are fundamental } \\
\text { to communication and public relations }\end{array}$ \\
\hline $\begin{array}{l}\text { Measuring the effect on outcomes is preferred } \\
\text { to measuring outputs }\end{array}$ & $\begin{array}{l}\text { Measuring communication outcomes is } \\
\text { recommended versus measuring only outputs }\end{array}$ \\
\hline $\begin{array}{l}\text { The effect on business results can and should } \\
\text { be measured where possible }\end{array}$ & $\begin{array}{l}\text { The effect on organisational performance can } \\
\text { and should be measured where possible }\end{array}$ \\
\hline $\begin{array}{l}\text { Media measurement requires quantity and } \\
\text { quality }\end{array}$ & $\begin{array}{l}\text { Measurement and evaluation require both } \\
\text { qualitative and quantitative methods }\end{array}$ \\
\hline AVEs are not the value of public relations & AVEs are not the value of communications \\
\hline Social media can and should be measured & $\begin{array}{l}\text { Social media can and should be measured } \\
\text { consistently with other media channels }\end{array}$ \\
\hline $\begin{array}{l}\text { Transparency and replicability are paramount to } \\
\text { sound measurement }\end{array}$ & $\begin{array}{l}\text { Measurement and evaluation should be } \\
\text { transparent, consistent, and valid }\end{array}$ \\
\hline
\end{tabular}

\section{The stasis in PR measurement and evaluation}

Despite this growing academic and industry attention, M\&E in PR practice is characterised by "stasis" (Gregory and Watson, 2008), or what Macnamara (2015) more recently referred to as a "deadlock" (for brevity the term 'PR' will be used from here on to include largely synonymous fields such as corporate, organisational, and strategic communication). In the United States, Michaelson and Stacks reported that "public relations practitioners have consistently failed to achieve consensus on what the basic evaluative measures are or how to conduct the underlying research for evaluating and measuring public relations performance" (2011, p. 1). The 2012 European Communication Monitor, based on a survey of 2,200 communication practitioners in 42 European countries, reported that $75 \%$ of European practitioners identified inability "to prove the impact of communication activities on organisational goals" as a "major barrier to further professionalisation and growth" (Zerfass, Verčič, Verhoeven, Moreno, \& Tench, 2012, p. 36).

Wright and Hinson (2012) reported that the industry's struggle with measurement and evaluation continues in digital and social media despite more readily available data on audience interaction with content and audience feedback. A longitudinal study of social media use by PR practitioners from 2006 to 2012 by Wright and Hinson (2012) found that only around half (54\%) measured what external publics said about them in blogs or other social media, and only one quarter (26\%) reported that they measure the impact of social media communication on the formation, change and reinforcement of attitudes, opinions and behaviour.

The lack of rigorous measurement and evaluation of PR is paradoxical given that the field of practice is growing rapidly - e.g., by $8-10 \%$ a year in developed markets and by more than $20 \%$ a year in some fast developing markets (ICCO, 2013) - and allegedly becoming increasingly professionalised (Gregory, 2009, 2011). It begs the question: why do practitioners fail to evaluate their work when budgets are increasing and the field is reportedly becoming more professional? Reasons commonly given for lack of evaluation such as lack of budget 
(Wright, Gaunt, Leggetter, Daniels, \& Zerfass, 2009) appear to be no longer relevant given the industry's growth and the profitability of major PR firms such as Edelman, Ogilvy PR, and Hill \& Knowlton. The above question was one of a number explored in analysis of Asia-Pacific Communication Monitor data, which proved to be insightful as explained in the following analysis.

\section{The Asia-Pacific Communication Monitor}

In 2015 the first-ever comprehensive study of PR and corporate communication practice across Asia-Pacific (APAC) was undertaken based on the European Communication Monitor that has been conducted annually across more than 40 European countries since 2007 (http://www.communicationmonitor.eu). In 2014, the first Latin America Communication Monitor was conducted (http://www.latinamericancommunication.com). By modelling the Asia-Pacific Communication Monitor on the extensive European study that in 2015 canvassed the views of 2,253 respondents from 41 countries (Zerfass, Verčič, Verhoeven, Moreno, \& Tench, 2015) and its growing franchise in other regions, a large body of comparative data is available to identify trends and patterns worldwide, as well as differences.

While it could be expected that practices in APAC countries would reflect those in the US, UK, and Europe to some or even a significant extent given internationalisation of undergraduate and postgraduate education and multinational corporations operating globally, the Asia-Pacific Communication Monitor (Macnamara, Lwin, Adi, \& Zerfass, , 2015) potentially offered useful insights and new perspectives for several reasons. First, APAC is one of the fastest growing regions in the world economically in which PR is growing rapidly (ICCO, 2013). The researchers were interested in whether this rapid growth in 'new world' markets resulted in different ways of working. Second, APAC is a region with a number of countries that have centralised and controlled media, which could be expected to yield different patterns of practice than Western countries. Third, the concept of 'leapfrogging', a theory of development based on the economic development theories of Schumpeter (1942) in which developing countries bypass incumbent technologies and methods and move ahead of developed countries in many fields (Davison, Vogel, \& Harris, 2000; Goldemberg, 1998), could apply to practices. Highly industrialised countries can be held back by large investments in 'legacy systems' or being 'stuck in their ways' in terms of methods and practices (the status quo), so new fast-emerging markets are useful sites to explore change and innovation.

\section{Methodology}

To provide statistically reliable and comparable data with the European Communication Monitor and the recently introduced Latin America study, a quantitative approach was taken using an online survey. The survey questionnaire comprised 26 questions, most using a fivepoint Likert scale for responses, arranged under 14 thematic sections, one of which was measurement and evaluation (M\&E).

Questions were based on those in the European Communication Monitor, which provided criterion validity for the survey (Frey, Botan, \& Kreps, 2000, p. 117), with some minor additions and variations to meet local cultural conditions and terminology. Adaptation to local conditions and supervision of the study were provided by a collaborative team of 16 researchers from universities across the region. This afforded content validity using an 'expert jury' method (Reinard, 2007). The survey questionnaire was administered in English only, given that PR practitioners in the region mostly speak English fluently as well as other native languages.

Measurement and evaluation have been examined at four levels in the European Communication Monitor over the past five years - inputs, outputs, outcomes, and outflows 
(DPRG \& ICV, 2011; Zerfass, 2010; Watson \& Noble, 2014). To allow global comparison, this framework was used in examining the views and practices of APAC PR and communication practitioners in relation to $\mathrm{M} \& \mathrm{E}$ - although it is noted that some researchers split outcomes into direct outcomes and organisational or business outcomes, the latter being the same as what others call outflows (GCS, 2015; PRIA, 2014). Some add outtakes to the model and define four or more stages of communication management including inputs, outputs, outtakes, outcomes, and outflows or impact (GCS, 2015; Macnamara, 2015; PRIA, 2014).

\section{Sample}

More than 21,000 pre-qualified PR and communication practitioners in 23 APAC countries whose names and contact details were held in a database of the Asia-Pacific Association of Communication Directors (APACD) were invited to complete the survey via e-mail. Additional invitations were sent by national research collaborators and other APAC associations of PR and communication practitioners that supported the survey. The recruitment of participants from relevant professional associations, combined with qualifying questions related to respondents' position and role, ensured control of the purposive sample.

The online survey was pre-tested in July 2015 with 68 communication practitioners in 14 APAC countries. Amendments were made where appropriate and the final questionnaire was activated for four weeks in August 2015, during which a total of 2,154 respondents started the survey, with 1,200 participants submitting a fully completed questionnaire. Incomplete responses were deleted from the dataset.

Three-quarters of the respondents hold senior communication leadership or management roles. Of these, $43.8 \%$ hold the most senior communication position in their organisation as head of communication or CEO of a communication consultancy, and $33.2 \%$ are unit leaders or in charge of a communication practice (e.g., media relations). Almost two-thirds (62.7\%) of the respondents have more than 10 years of experience, and most are highly educated with $96.9 \%$ holding a diploma or degree and 55.9\% holding at least one university degree. More than half (56.9\%) are female and the average age across the sample is 41 years. This illustrates that responses were gained from mature, well-educated PR and communication practitioners in senior positions.

Analysis also shows that responses were gained from practitioners employed in multinational and local organisations including public companies, private companies, government, non-profit organisations, and consultancies/agencies. A quarter of the respondents (25.7\%) work in multinational organisations founded or headquartered in APAC, while $31.8 \%$ represent multinational organisations headquartered on another continent. However, strong representation from local organisations was gained with $38.8 \%$ of respondents working for national or local organisations in the country in which they are located. Almost three out of four respondents work internally in organisations - 38.3\% in public companies, $17.1 \%$ in private companies; $11.9 \%$ in government, and $7.8 \%$ in non-profit organisations - while $24.9 \%$ are consultants working freelance or for agencies.

Overall, 23 countries participated in the survey. The countries with the largest number of respondents were India, Australia, Singapore, Hong Kong and China, followed by Vietnam, Thailand and Malaysia. The dataset provided detailed and moderately reliable insights for the top 10-14 countries and particularly for the 'top 8' (see Table 2). 
Table 2. Number of responses from Asia-Pacific countries surveyed.

\begin{tabular}{lcr}
\hline Country & Respondents & Percentage \\
\hline $\begin{array}{l}\text { Significant number of responses: } \\
\text { India }\end{array}$ & 164 & \\
\hline Australia & 156 & $13.7 \%$ \\
\hline Singapore & 137 & $13.0 \%$ \\
\hline Hong Kong & 128 & $11.4 \%$ \\
\hline China & 104 & $10.7 \%$ \\
\hline Vietnam & 90 & $8.7 \%$ \\
\hline Thailand & 67 & $7.5 \%$ \\
\hline Malaysia & 62 & $5.6 \%$ \\
\hline Taiwan & 55 & $5.2 \%$ \\
\hline New Zealand & 53 & $4.6 \%$ \\
\hline Japan & 51 & $4.4 \%$ \\
\hline Indonesia & 46 & $4.3 \%$ \\
\hline Philippines & 39 & $3.8 \%$ \\
\hline Korea & 33 & $3.3 \%$ \\
\hline Not significant number of responses: & & $2.8 \%$ \\
\hline Pakistan & 4 & \\
\hline Bangladesh & 2 & $0.3 \%$ \\
\hline Cambodia & 2 & $0.2 \%$ \\
\hline Sri Lanka & 2 & $0.2 \%$ \\
\hline Fiji & 1 & $0.2 \%$ \\
\hline Laos & 1 & $0.1 \%$ \\
\hline Macau & 1 & $0.1 \%$ \\
\hline Myanmar & 1 & $0.1 \%$ \\
\hline Nepal & $100 \%$ \\
\hline Total responses & & $0.1 \%$ \\
\hline & 1 & \\
\hline
\end{tabular}

\section{Data analysis}

The Statistical Package for the Social Sciences (SPSS) was used for data analysis. Depending on the variable, results were tested statistically using Pearson's chi-square tests $\left(\chi^{2}\right)$, ANOVA/Scheffe post-hoc tests, Kendall rank correlation, and/or $t$-tests. Percentages reported in the findings indicate the agreement of respondents based on the top two values of 5-point Likert scales.

\section{Findings - Measurement and evaluation in Asia-Pacific}

\section{The big issues}

Coping with 'the digital evolution and social web' is perceived as the most important issue for PR practitioners in APAC over the next three years (2016-2018), nominated by $53.1 \%$ of respondents. This contrasts with findings of the European Communication Monitor in 2014 and 2015 in which linking communication to business strategy, which requires evaluation, was identified as the most important issue (Zerfass, Tench, Verčič, Verhoeven, \& Moreno, 2014; Zerfass et al., 2015). In Asia-Pacific, linking communication to business strategy, including 
showing the contribution of communication to organisational outcomes, is seen as the second most important issue for practitioners (41.0\%).

APAC PR practitioners are at one with their European colleagues in seeing building and maintaining trust as the third most important issue. However, of concern in the context of this analysis is that implementing advanced measurement and evaluation overall is rated as the most important issue by only $15.7 \%$ of PR practitioners in the region. This reflects a similar low rating of importance by practitioners in the 2015 European Communication Monitor (Zerfass et al., 2015, p. 40).

In terms of desired outcomes of PR and communication, reputation is a particularly high priority in the Philippines (92.3\%); New Zealand (86.8\%); Australia (86.5\%); Indonesia (82.6\%); Singapore (81.8\%); India (81.7\%); Malaysia (80.6\%); and Japan (80.4\%), followed closely by Hong Kong, Korea, and Taiwan. Economic impact is most important in the Philippines (84.6\%), while demonstrating thought leadership is important in Malaysia (83.9\%); the Philippines (76.9\%); Hong Kong (75.8\%); and India (75.6\%). However, only $60.8 \%$ of Asia-Pacific PR practitioners attempt to demonstrate positive economic consequences such as effects on sales or employee motivation and productivity.

\section{Evaluation focussed on outputs}

Counting of media clippings and media response (e.g., favourable articles) remains the predominant method of measurement and evaluation, used by $85.6 \%$ of $\mathrm{PR}$ a practitioners in APAC. This exceeds the reliance on clippings and media response in Europe where $82.4 \%$ of practitioners rely on these methods (Zerfass et al., 2015, p. 72). APAC practitioners also rely heavily on other 'output' measures including internet/intranet use (67.8\%) and internal client satisfaction (66.2\%).

Figure 1. How communication departments assess the effectiveness of their activities.

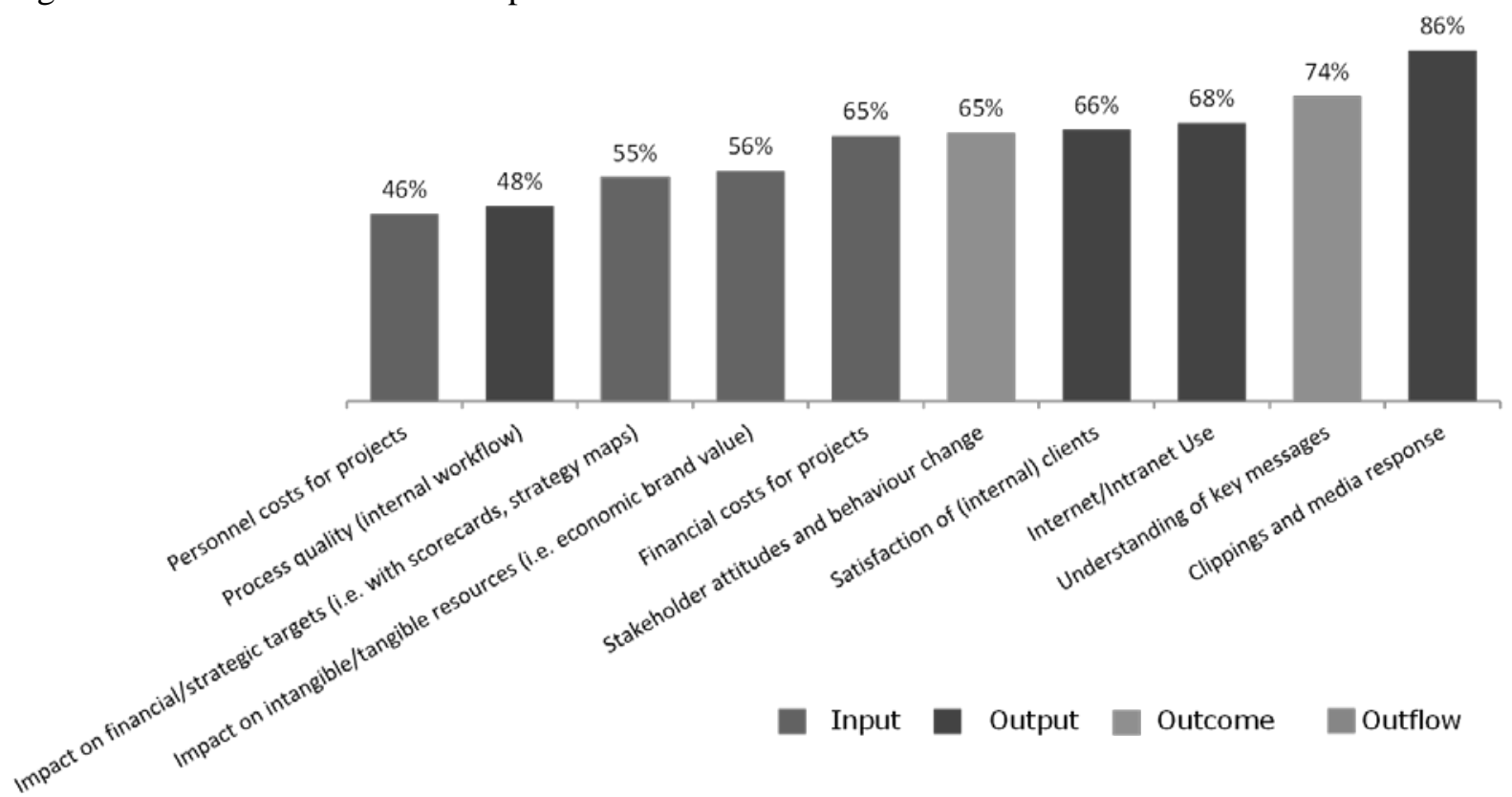

Q: Which items are monitored or measured by your organisation to assess the effectiveness of communication management / public relations? Scale 1 (Do not use at all) -5 (Use continuously). $n=847$ PR professionals working in communication departments. Percentages: Frequency based on scale points 4-5. 
The second most used metric is understanding of key messages (74.4\%), and 65.5\% claim to measure stakeholders attitudes and behaviour change, which the 'communication controlling' model of evaluation describes as 'outcomes'. Some other evaluation models describe these as 'outtakes' or 'direct outcomes' (as distinct from organisational outcomes or impact).

Overall, most focus in measurement and evaluation is on outputs such as production of content and media coverage (76.7\%), followed by direct immediate outcomes such as utilisation of information (receipt) and knowledge (awareness) (74.7\%). Only slightly more than half of PR practitioners in APAC (55.3\%) measure value at an outflow level such as impact on strategic and/or financial targets or tangible or intangible resources, and only two-thirds of APAC practitioners (65.5\%) evaluate audience opinion, attitudes, or behavioural disposition (e.g., intentions). Also, only slightly more than half of practitioners pay attention to evaluating internal outputs such as process efficiency and quality (56.9\%).

\section{Talking the digital talk}

Traditional media relations addressing print newspapers or magazines continue to be seen as the most important channels of communication (by 76.5\% of respondents), although social media are now almost level-pegging with traditional media in terms of perceived importance in APAC with $75.0 \%$ of PR practitioners rating social media as important. Online communication via Web sites, intranets, and e-mail are also seen as important (73.6\%), as well as media relations with online newspapers or magazines (73.2\%). (See Figure 2.)

Figure 2. Importance of various channels and instruments for strategic communication in Asia-Pacific today.

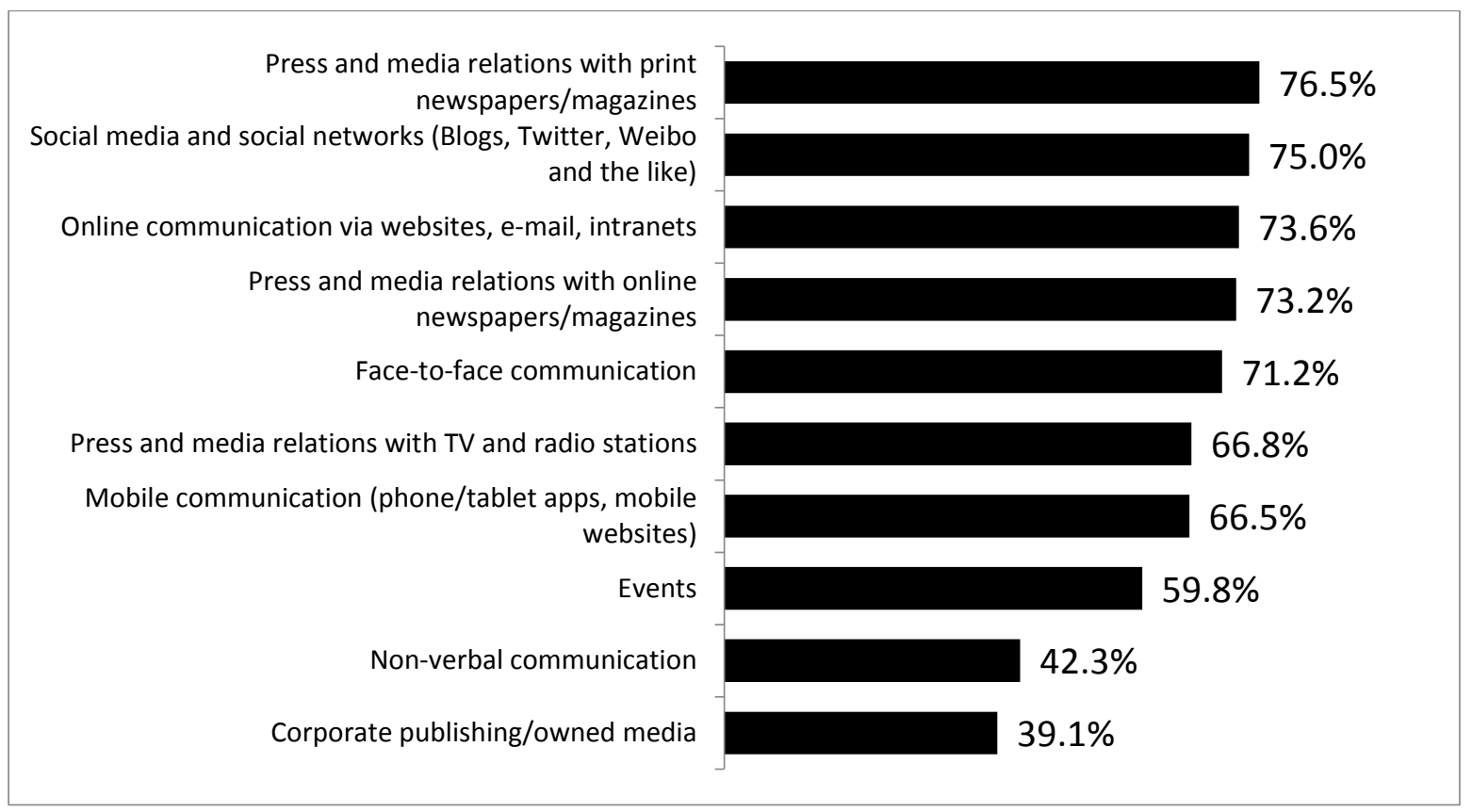

Q: How important are the following methods in addressing stakeholders, gatekeepers and audiences today? Scale 1 (Not important) - 5 (Very important). $n=1,148$ PR professionals. Percentages: Frequency based on scale points $4-5$.

However, when PR and communication practitioners look three years into the future to 2018, only $46.9 \%$ see media relations with print media as important and only $53.7 \%$ see media relations with radio and TV as important. In comparison, 92.2\% rate social media such as blogs, 
Twitter, Weibo, and so on, as important for strategic communication and $85.6 \%$ favour websites, intranets and e-mail.

Figure 3. Expected development of communication channels in Asia-Pacific 2015-2018.

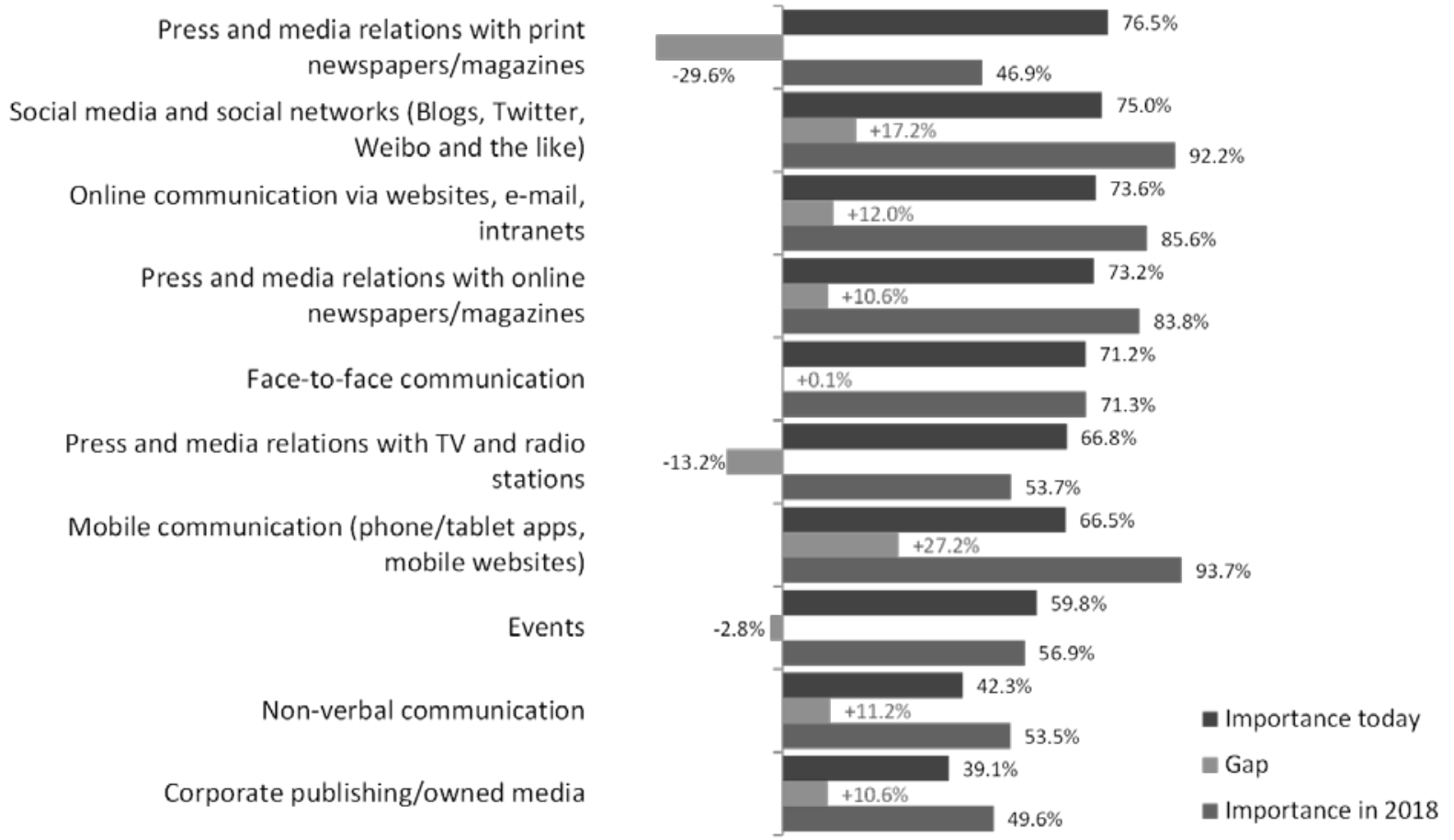

Q 4: How important are the following methods in addressing stakeholders, gatekeepers and audiences today? In your opinion, how important will they be in three years? Scale 1 (Not important) -5 (Very important). $\mathrm{n}=$ 1,148 PR professionals. Percentages: Frequency based on scale points 4-5.

Also 94\% of APAC PR practitioners see mobile communication as important by 2018, compared with two-thirds of practitioners who see it as important today. Mobile applications are seen as most important in Malaysia, the Philippines, Thailand, and Taiwan.

\section{But not walking the walk - lack of knowledge and skills}

Despite the growing importance of social media, less than half of APAC PR practitioners say they know how to evaluate social media activities (44.8\%). While $61.2 \%$ of APAC practitioners say they know about social media trends in general and delivering messages through social media, a minority say they can set up a social media platform (46.5\%); manage online communities (44.5\%); or interpret social media monitoring data (45.2\%). Only one-third (33.1\%) know the legal framework applying to social media and just $31.8 \%$ of APAC communication professionals say they can initiate web-based dialogue with stakeholders - one of the key affordances of interactive social media (Kaplan \& Haenlein, 2010).

Skills and knowledge in relation to social media are relatively consistent across the region, although Taiwan, China, and Indonesia report slightly higher levels. Australia and New Zealand reportedly lag in social media skills and knowledge, which is a concerning finding for these highly developed markets. Some of the highest levels of social media skills and knowledge in relation to knowing about social media trends, developing social media strategies, and avoiding risks and managing crises in social media were reported in Taiwan, the Philippines, and Indonesia. Some of the lowest levels of skills were reported in Hong Kong, Australia, and New Zealand in relation to initiating dialogue with stakeholders online and 
interpreting social media monitoring data, as well as understanding the legal framework applying to social media and evaluating social media activities.

Overall, PR practitioners report far more emphasis on delivering messages via social media than initiating dialogue with stakeholders. This illustrates Macnamara's recent research finding that most public communication is focussed on speaking, with a lack of attention to two-way communication including listening (Macnamara, 2013, 2016). Also, this reflects findings in the US by Kent (2013), Taylor and Kent (2014), Wright and Hinson (2012), and others that PR practitioners are using interactive social media to broadcast messages rather than engage in dialogue.

What could be described as a disappointing level of skills and knowledge about social media explains at least in part why 'coping with the digital evolution and the social web' is identified as the major issue facing PR practitioners between now and 2018. Also, the relatively low level of skills and knowledge in relation to interpreting social media monitoring data (just $45.2 \%$ report having such skills), and the even-lower $44.8 \%$ who say they know how to evaluate social media activities, show that measurement and evaluation collectively remains an ongoing challenge for communication professionals.

These findings closely reflect skills and knowledge levels of European practitioners reported by Tench and Moreno (2015), Zerfass, Moreno, Tench, Verčič, \& Verhoeven (2013, pp. 3849), and Zerfass et al. (2014, 2015), and suggest that increased professional development is required globally.

\section{The PESO model flips without measure}

In contrast with the traditional model of media use by organisations known as PESO (paid, earned, shared, owned) in which paid advertising and editorial (earned coverage) have been the dominant focus, PR practitioners in APAC foresee an increase in use of owned media (56.3 per cent) as well as shared media such as social media. Studies have shown that owned media are expanding well beyond traditional corporate publishing of house journals, annual reports, and Web sites to include an array of new content formats described as 'native advertising' (paid promotion that is presented to not look like advertising) and other euphemistic terms such as sponsored content, brand integration, and 'embedded marketing' (Macnamara, 2014). While providing new opportunities for marketers and media proprietors, some of these new formats are raising questions about transparency and ethics, as they blur the boundaries between paid promotion and news. However, no evidence was found in the Asia-Pacific Communication Monitor study to indicate that practitioners are evaluating new forms of owned media either to track their effectiveness or their compliance with codes of ethics. This reveals a further gap in practice related to $\mathrm{M} \& \mathrm{E}$.

\section{Discussion and conclusions}

Despite including a number of fast-growing markets characterised by 'leapfrogging' in technology and methods as well as burgeoning PR departments and agencies, Asia-Pacific has not produced innovation or major change in PR practice compared with Europe or other developed markets. In fact, the major issues identified by practitioners, activities seen as important, and methods used closely parallel those identified in Western studies such as the European Communication Monitor 2015 (Zerfass et al., 2015).

In particular, measurement and evaluation collectively remains a challenge and is rated as a lower priority in Asia-Pacific than it is in Europe where it is already seen to be receiving insufficient attention. At the same time, lack of knowledge and skills in relation to digital media 
and evaluation methods is evident as a major gap affecting capabilities and competencies in both Asia-Pacific and European studies of practitioners.

In 50 years of intensive focus on measurement and evaluation of PR and corporate communication a number of explanations have been advanced for the low levels of implementation in practice including lack of budget, lack of time, lack of client interest, and a search for a single “silver bullet' (Gregory \& White, 2008; Likely \& Watson, 2013, p. 156) all of which have been challenged and dismissed by research studies (e.g., Baskin, Hahn, Seaman, \& Reines, 2010; Lindenmann, 2001; Macnamara, 2015; Watson \& Noble, 2014).

Comparison of data from two of the largest studies of practitioners internationally - the AsiaPacific Communication Monitor 2015 and the European Communication Monitor 2015 and in previous years - shows strong correlation between low level of evaluation and low levels of knowledge and skills among practitioners. While a direct causal relationship is not fully proven in these studies - their objectives were much broader yielding a range of findings about contemporary PR practices - the combination of correlation and the ruling out of other explanations in previous studies establishes a strong probability of causality. Therefore, this study provides useful insights into this perplexing hiatus and a direction for further research and industry professional development.

While the PR industry is enjoying continuing growth, its level of professionalism, its ability to demonstrate its results, and the capability of practitioners to adapt to future communication technologies and methods will depend on significant increases in knowledge and skills in relation to digital media as well as measurement and evaluation. Given that most if not all universities offering undergraduate and postgraduate courses in PR, public communication, and strategic communication include subjects on communication and media research, and most PR industry associations offer short courses on measurement and evaluation as part of professional development programs, future research should include investigation of whether there are cultural or other barriers preventing practitioners from accessing available learning opportunities, as well as the suitability and adequacy of learning resources. Other avenues for productive future research include identifying any correlations between practitioners who have undertaken training in research and higher levels of implementation of M\&E, and tracking of practitioners post-attendance at courses and professional development programs in measurement and evaluation to identify any changes in their subsequent practice (e.g., do they increase and improve $M \& E$ as a result of training).

Improvement in measurement and evaluation of the impact and effects of public relations is necessary for organisations in a management environment of accountability and for society in view of the substantial and continuing growth and expansion of PR.

\section{References}

AMEC (Association for Measurement and Evaluation of Communication). (2015a). Barcelona Principles 2.0. London, UK: Author. Retrieved from http://amecorg.com/barcelona-principles-2-0infographic

AMEC (Association for Measurement and Evaluation of Communication). (2015b). The PR professional's definitive guide to measurement. London, UK: Author. Retrieved from http://prguidetomeasurement.org

Baskin, O., Hahn, J., Seaman, S., \& Reines, D. (2010). Perceived effectiveness and implementation of public relations measurement and evaluation tools among European providers and consumers of PR services. Public Relations Review, 36(2), 105-111. doi.org/10.1016/j.pubrev.2010.02.002

Broom, G. and Dozier, D. (1983). An overview: Evaluation research in public relations. Public Relations Quarterly, 28(3), 5-9. 
Broom, G., \& Dozier, D. (1990). Using research in public relations: Applications to program management. Englewood Cliffs, NJ: Prentice-Hall.

Clark, H., \& Taplin, D. (2012). Theory of change Basics: A primer on theory of change. New York, NY: Actknowledge.

Cutlip, S., \& Center, A. (1952). Effective public relations. Englewood Cliffs, NJ: Prentice-Hall.

Cutlip, S., \& Center, A. (1958). Effective public relations (2nd ed.). Englewood Cliffs, NJ: PrenticeHall.

Cutlip, M., Center, A., \& Broom, G. (1985). Effective public relations (6th ed.). Englewood Cliffs, NJ: Prentice Hall.

Cutlip, M., Center, A., Broom, G. (2009). Effective public relations (10th ed.). Upper Saddle River, NJ: Prentice Hall.

Davison, R., Vogel, D., \& Harris, R. (2000). Technology leapfrogging in developing countries: An inevitable luxury? The Electronic Journal of Information Systems in Developing Countries, 1(5), 1-10. Retrieved from http://www.ejisdc.org/ojs2/index.php/ejisdc/article/view/5/5

Dozier, D. (1984). Program evaluation and the roles of practitioners. Public Relations Review, 10(2), 13-21. doi.org/10.1016/S0363-8111(84)80002-8

Dozier, D. (1985). Planning and evaluation in public relations practice. Public Relations Review, 11(2), 17-25.

DPRG \& ICV. (2011). Position paper Communication Controlling: How to maximize and demonstrate the value creation through communication. Bonn, Gauting: Deutsche Public Relations Gesellschaft, Internationaler Controller-Verein.

Ehling, W. (1992). Estimating the value of public relations and communication to an organisation. In J. Grunig (Ed.), Excellence in public relations and communication management pp. 617-638). Hillsdale, NJ: Lawrence Erlbaum.

Frey, L. Botan, C., \& Kreps, G. (2000). Investigating communication: An introduction to research methods. Needham Heights, MA: Allyn \& Bacon.

GCS (Government Communication Service). (2015). Evaluation framework. Whitehall, UK: Cabinet Office.

Goldemberg, J. (1998). Leapfrogging energy technologies. Energy Policy, 2(10), 729-741.

Gregory, A. (2009). Ethics and professionalism in public relations. In R. Tench \& L. Yeomans (Eds.), Exploring public relations (2nd ed., pp. 273-289). Harlow, UK: Pearson Education.

Gregory, A. (2011). The state of the public relations profession in the UK: A review of the first decade of the twenty-first century. Corporate Communications, 16(2), 89-104. doi.org/10.1108/13563281111141633

Gregory, A., \& Watson, T. (2008). Defining the gap between research and practice in public relations programme evaluation: Towards a new research agenda. Journal of Marketing Communications, 24(5), 337-350. doi.org/10.1080/13527260701869098

Gregory, A., \& White, T. (2008). Introducing the Chartered Institute of Public Relations initiative. In B. van Ruler, A. Verčič, \& D. Verčič (Eds.), Public relations metrics: Research and evaluation (pp. 307-317). New York, NY: Routledge.

Grunig, J. (1979). The status of public relations research. Public Relations Quarterly, 20(1), 5-8.

Grunig, J. (1983). Basic research provides knowledge that makes evaluation possible. Public Relations Quarterly, 28(3), 28-32.

Grunig, J., Grunig, L., \& Dozier, D. (2006). The excellence theory. In C. Botan \& V. Hazelton (Eds.), Public relations theory II (pp. 21-62). Mahwah, NJ: Lawrence Erlbaum.

Grunig, L., Grunig, J., \& Dozier, D. (2002). Excellent organizations and effective organizations: A study of communication management in three countries. Mahwah, NJ: Lawrence Erlbaum.

Grunig, J., Hunt, T. (1984). Managing public relations. Orlando, FL: Holt, Rinehart \& Winston.

ICCO (International Communications Consultancy Organisation) (2013). ICCO world report. London, UK: Author. Retrieved from http://www.iccopr.com/knowledge-base/Worldreports.aspx

IPR (Institute for Public Relations). (2015). Public relations research standards center. Gainesville, FL: Author. Retrieved from http://www.instituteforpr.org/public-relations-research-standards

Julian, D. (1997). The utilisation of the logic model as a system level planning and evaluation device. Evaluation and Program Planning, 20(3), 251-257.

Kaplan, R., \& Haenlein, M. (2010). Users of the world, unite! The challenges and opportunities of social media. Business Horizons, 53(1), 59-68. doi.org/10.1016/j.bushor.2009.09.003 
Kellogg Foundation. (2004). Logic model development guide. Battle Creek, MI: Author. Retrieved from http://www.epa.gov/evaluate/pdf/eval-guides/logic-model-development-guide.pdf

Kent, M. (2013). Using social media dialogically: Public relations role in reviving democracy. Public Relations Review, 39(4), 337-345. doi.org/10.1016/j.pubrev.2013.07.024

Knowlton, L., \& Phillips, C. (2013). The logic models guidebook: Better strategies for great results (2nd ed.). Thousand Oaks, CA: Sage.

L’Etang, J. (2008). Public relations: Concepts, practice and critique. London, UK: Sage.

Likely, F. (2012, March). Principles for the use of return on investment (ROI), benefit-cost ration (BCR) and cost-effectiveness analysis (CEA) financial metrics in a public relations/communication (PR/C) department. Paper presented to the 15th international public relations research conference, Miami, FL.

Likely, F., \& Watson, T. (2013). Measuring the edifice: Public relations measurement and evaluation practice over the course of 40 years. In K. Sriramesh, A. Zerfass, \& J. Kim (Eds.), Public relations and communication management: Current trends and emerging topics (pp. 143-162). New York, NY: Routledge.

Lindenmann, W. (1979). The missing link in public relations research. Public Relations Review, 5(1), 26-36. doi.org/10.1016/S0363-8111(79)80005-3

Lindenmann, W. (1980). Hunches no longer suffice. Public Relations Journal, 36(6), 9-13.

Lindenmann. W. (1993). An 'effectiveness yardstick' to measure public relations success. $P R$ Quarterly, 38(1), 7-9.

Lindenmann, W. (2001). Research doesn't have to put you in the poorhouse. Gainesville, FL: Institute for Public Relations. Retrieved from http://www.instituteforpr.org/topics/research-savings

Macnamara, J. (1999). Research in public relations: A review of the use of evaluation and formative research. Asia-Pacific Public Relations Review, 1(2), 107-133.

Macnamara, J. (2012). Public relations theories, practices, critiques. Sydney, NSW: Pearson.

Macnamara, J. (2013). Beyond voice. Audience-making and the work and architecture of listening. Continuum: Journal of Media and Cultural Studies, 27(1), 160-175.

Macnamara, J. (2014). Journalism and PR: Unpacking 'spin', stereotypes, and media myths. New York, NY: Peter Lang.

Macnamara, J. (2015). Breaking the measurement and evaluation deadlock: A new approach and model. Journal of Communication Management, 19(4), 371-387. doi.org/10.1108/JCOM-042014-0020

Macnamara, J. (2016). Organizational listening: The missing link in public communication. New York, NY: Peter Lang.

Michaelson, D., \& Stacks, D. (2011). Standardization in public relations measurement and evaluation. Public Relations Journal, 5(2), 1-22.

Noble, P., \& Watson, T. (1999). Applying a unified public relations evaluation model in a European context. Paper presented to the transnational communication in Europe: Practice and research congress, Berlin, Germany.

Pavlik, J. (1987). Public relations: What research tells us. Newbury Park, CA: Sage.

PRIA (Public Relations Institute of Australia). (2014). Principles on best practice research, measurement, and evaluation in public relations. Sydney, NSW: PRIA. Retrieved from http://www.pria.com.au/documents/item/6726

Reinard, J. (2007). Introduction to communication research (4th ed.). Boston, MA: McGraw Hill.

Schumpeter, J. (1942). Capitalism, socialism and democracy. New York, NY: Harper.

Stacks, D., \& Michaelson, D. (2014). A practitioner's guide to public relations research, measurement, and evaluation (2nd ed.). New York, NY: Business Experts Press.

Taylor, M., \& Kent, M. (2014). Dialogic engagement: Clarifying foundational concepts. Journal of Public Relations Research, 26(5), 384-398. doi.org/10.1080/1062726X.2014.956106

Tench, R., \& Moreno, A. (2015). Mapping communication management competencies for European practitioners: ECOPSI an EU study. Journal of Communication Management, 19(1), 39-61. doi.org/10.1108/JCOM-11-2013-0078

Volk, S. C. (2016, March). A systematic review of 40 years of public relations evaluation and measurement research: Looking into the past, the present, and the future. Paper presented at the International Public Relations Research Conference, Miami, FL. 
Watson, T. (1997). Measuring the success rate: Evaluating the PR process and PR programmes. In P. Kitchen (Ed.), Public relations principles and practice (pp. 283-299). London, UK: International Thomson Business Press.

Watson, T. (2012). The evolution of public relations measurement and evaluation. Public Relations Review, 38(3), 390-398. doi.org/10.1016/j.pubrev.2011.12.018

Watson, T., \& Noble, P. (2014). Evaluating public relations. A guide to planning, research and measurement (3rd ed.). London, UK: Kogan Page.

Watson, T., \& Zerfass, A. (2011). Return on investment in public relations: A critique of concepts used by practitioners from communication and management sciences perspectives. PRism, 8(1), 114. Retrieved from http://www.prismjournal.org/vol8_1.html

Watson, T., \& Zerfass, A. (2012, March). ROI and PR evaluation: Avoiding 'smoke and mirrors'. International public relations research conference, Miami, FL. Retrieved from http://www.instituteforpr.org/iprwp/wp-content/uploads/Watson-Zerfass-ROI-IPRRC-Miami20121.pdf

Wright, D., \& Hinson, M. (2012). Examining how social and emerging media have been used in public relations between 2006 and 2012: A longitudinal analysis. Public Relations Journal, 6(4), $1-40$.

Wright, D., Gaunt, R., Leggetter, B., Daniels, M., \& Zerfass, A. (2009). Global survey of communications measurement 2009; Final report. London, UK: Association for Measurement and Evaluation of Communication. Retrieved from http://amecorg.com/wpcontent/uploads/2011/08/Global-Survey-Communications_Measurement-20091.pdf

Zerfass, A. (2010). Assuring rationality and transparency in corporate communications. Theoretical foundations and empirical findings on communication controlling and communication performance management. In M. D. Dodd \& K. Yamamura (Eds.), Ethical issues for public relations practice in a multicultural world, 13th International public relations research conference (pp. 947-966). Gainesville, FL: Institute for Public Relations.

Zerfass, A., Moreno, A., Tench, R., Verčič, D., \& Verhoeven, P. (2013). European communication monitor 2013. A changing landscape - Managing crises, digital communication and CEO positioning in Europe. Results of a survey in 43 countries. Brussels, Belgium: European Association of Communication Directors (EACD), European Public Relations Education, and Research Association (EUPRERA), and Helios Media.

Zerfass, A., Tench, R., Verčič, D., Verhoeven, P., \& Moreno, A. (2014). European Communication Monitor 2014: Excellence in strategic communication - Key issues, leadership, gender and mobile media. Results of a survey in 42 countries. Brussels, Belgium: European Association of Communication Directors (EACD), European Public Relations Education, and Research Association (EUPRERA), and Helios Media.

Zerfass, A., Verčič, D., Verhoeven, P., Moreno, A., \& Tench, R. (2015). European communication monitor 2015: Creating communication value through listening, messaging and measurement. Results of a survey in 41 countries. Brussels, Belgium: European Association of Communication Directors (EACD), European Public Relations Education, and Research Association (EUPRERA), and Helios Media.

\section{The authors}

Jim Macnamara PhD is Professor of Public Communication at the University of Technology Sydney, a position he took up in 2007 after a 30-year professional career spanning journalism, public relations and media research. He is the author of 15 books including The $21^{\text {st }}$ Century Media (R)evolution: Emergent Communication Practices (Peter Lang, New York, 2014) and Organizational Listening: The Missing Essential in Public Communication (Peter Lang, New York, 2016).

Ansgar Zerfass $\mathrm{PhD}$ is Professor and Chair in Strategic Communication in the Institute of Communication and Media Studies at the University of Leipzig. He is also a Professor in Communication and Leadership at BI Norwegian Business School, Oslo, and editor of the International Journal of Strategic Communication (Routledge). He is the author or co-author of 32 books and more than 270 articles and research reports in multiple languages including the European Communication Monitor and Asia-Pacific Communication Monitor. 


\section{Acknowledgements}

The Asia-Pacific Communication Monitor was supported by PRIME Research International; Communication Director magazine; the Asia-Pacific Association of Communication Directors (APACD); the European Public Relations Education and Research Association (EUPRERA); and Quadriga University of Applied Sciences, Berlin. In addition, the authors acknowledge and thank staff at 14 universities across APAC who assisted in this research: Chulalongkorn University, Bangkok, Thailand; Chung-Ang University, Seoul, Korea; Fu-Jen Catholic University, Taipei, Taiwan; Hokkaido University, Sapporo, Japan; Hong Kong Baptist University; Indian Institute of Mass Communication, New Delhi ; Massey University, Auckland, New Zealand; Nanyang Technological University, Singapore; Sun Yat-Sen University, Guangzhou, China; Trisakti University, Jakarta, Indonesia; Universiti Technologi MARA, Selangor, Malaysia; University of Technology Sydney, Australia; University of the Philippines, Diliman; and Vietnam National University, Hanoi.

\section{Published reference:}

Macnamara J., \& Zerfass, A. (2017). Evaluation stasis continues in PR and corporate communication: Asia Pacific insights into causes. Communication Research and Practice. doi.org/10.1080/22041451.2017.1275258 